\title{
HILGARDIA
}

A Journal of Agricultural Science Published by the California Agricultural Experiment Station

\section{THE DETERMINATION OF YIELD AND SHRINKAGE OF WOOL BY SCOURING SMALL SAMPLES}

J. F. WIISON

SINGLE AND MULTIPLE FIBER TESTS FOR DETERMINING COMPARATIVE BREAKING LOADS OF WOOL FIBERS

J. F. WILSON and E. B. ROESSLER 


\title{
$\begin{array}{lllllllll}\text { H } & \text { I } & \text { L } & G & A & R & D & \text { I } & \text { A }\end{array}$
}

A Journal of Agricultural Science Published by

the California. Agricultural Experiment Station

VoL. 11

JANUARY, 1938

No. 4

\section{THE DETERMINATION OF YIELD AND SHRINKAGE OF WOOL BY SCOURING SMALL SAMPLES ${ }^{1}$}

\author{
J. F. WILSON ${ }^{2}$
}

\section{INTRODUCTION}

The ACCURATE DETERMinAtion of wool shrinkage is essential to the proper conduct of biological investigations of quantitative wool production. It is equally important to the woolgrower. The clean weight of a fleece is far more significant than the grease weight in the selection of breeding animals, especially rams whose offspring are to be retained for breeding. Besides being important biologically, shrinkage is intimately associated with all commercial aspects of wool production. The price of the commodity is quoted on a clean basis, and each 1 per cent difference in the shrinkage affects the value per pound of either the individual fleece or the whole clip $1 / 100$ of the quoted price. Thus, if fine combing wool sells at 90 cents a pound on a clean basis, an increase of 1 per cent in the shrinkage decreases the value of the grease wool $9 / 10$ of a cent a pound. A grower with a band of 1,500 ewes shearing, on an average, 10 pounds each might be affected to the extent of $\$ 135$ by a 1 per cent variation in shrinkage, provided the clip is sold strictly on its merits.

The factors influencing shrinkage have been pointed out in another paper, ${ }^{(1) 3}$ which showed that California wools may shrink from 30 per cent to as high as 80 per cent.

Proper technique in shrinkage determinations has been studied over a long period at the California Agricultural Experiment Station and elsewhere. Hard $\mathrm{y}^{(2)}$ once recommended scouring the entire fleece for the most reliable results. In the absence of equipment to scour whole fleeces he

\footnotetext{
${ }^{1}$ Received for publication November 24, 1937.

${ }^{2}$ Associate Professor of Animal Husbandry and Associate Animal Husbandman in the Experiment Station.

${ }^{3}$ Superscript numbers in parentheses refer to "Literature Cited," at the end of this paper.
} 
recommended sorting the fleece into its various qualities and making up a sample consisting of 20 per cent of each sort. Wilson ${ }^{(3)}$ showed that both of these methods might have some disadvantages. Scouring whole fleeces was too laborious for a laboratory method; making up samples from the sorted fleece was tedious, time-consuming, and subject to possible error through loss of dirt. A fleece opener was developed at the California Station to mix fleeces into a homogeneous mass ${ }^{(3)}$ from which small samples accurately representing the lot could easily be drawn. The device has been copied by several experiment stations, and the principle of opening up the fleece and mixing it thoroughly before drawing samples has been demonstrated to be correct. The machine referred to has several faults: its design does not permit easy handling of the wool; it is unsuitable for any wools with a staple length greater than 4 inches; it tends to clog when fed too fast, necessitating frequent stops when fleeces of 3- to 4-inch staple are being tested; and it is difficult to clean.

\section{A NEW FLEECE OPENER FOR SHRINKAGE TESTS}

A new fleece opener possessing many advantages over the first one has been built and tested at the wool laboratory of the University of California." The interest evidenced by many agencies in wool-shrinkage determinations indicates the advisability of publishing a description of the apparatus.

The machine has been so designed that it is partially collapsible and, if tipped on one end, can be moved through a 3-foot door. This feature also permits a considerable saving in space when the machine is not in use. Care has been taken to specify parts usually obtainable in small cities. Any cabinet maker, with some aid from a blacksmith and a sheetmetal worker, should be able to construct it. It has proved satisfactory for wools with a staple length of 8 inches and eliminates much of the manual manipulation of wool necessary with the earlier machine.

The total cost, exclusive of the motor, should not exceed $\$ 200$.

The machine consists of a rotor or breaker cylinder in the form of a truncated cone, mounted in a frame of hard maple. The centrifugal force created by the whirling cylinder, and by its shape, causes the greasy wool to move rapidly from the smaller end toward the larger. In the course of its travel it is acted upon by the teeth of the cylinder and the teeth in the frame.

4 The author gratefully acknowledges the assistance of Norman C. Dale, farm advisor of Susquehanna County, Pennsylvania, in designing and constructing the new fleece opener. Mr. Dale, working as a graduate student in wool technology at the University of California, not only furnished some of the basic ideas incorporated in the machine, but built and rebuilt the working model until it proved satisfactory. 
Figure 1 shows elevations and plan of the frame. Mortise and tenon joints are further strengthened by iron rods embedded in grooves in the wooden members. These rods are upset on one end, and threaded on the other to receive nuts. Any tendency for the joints to loosen through
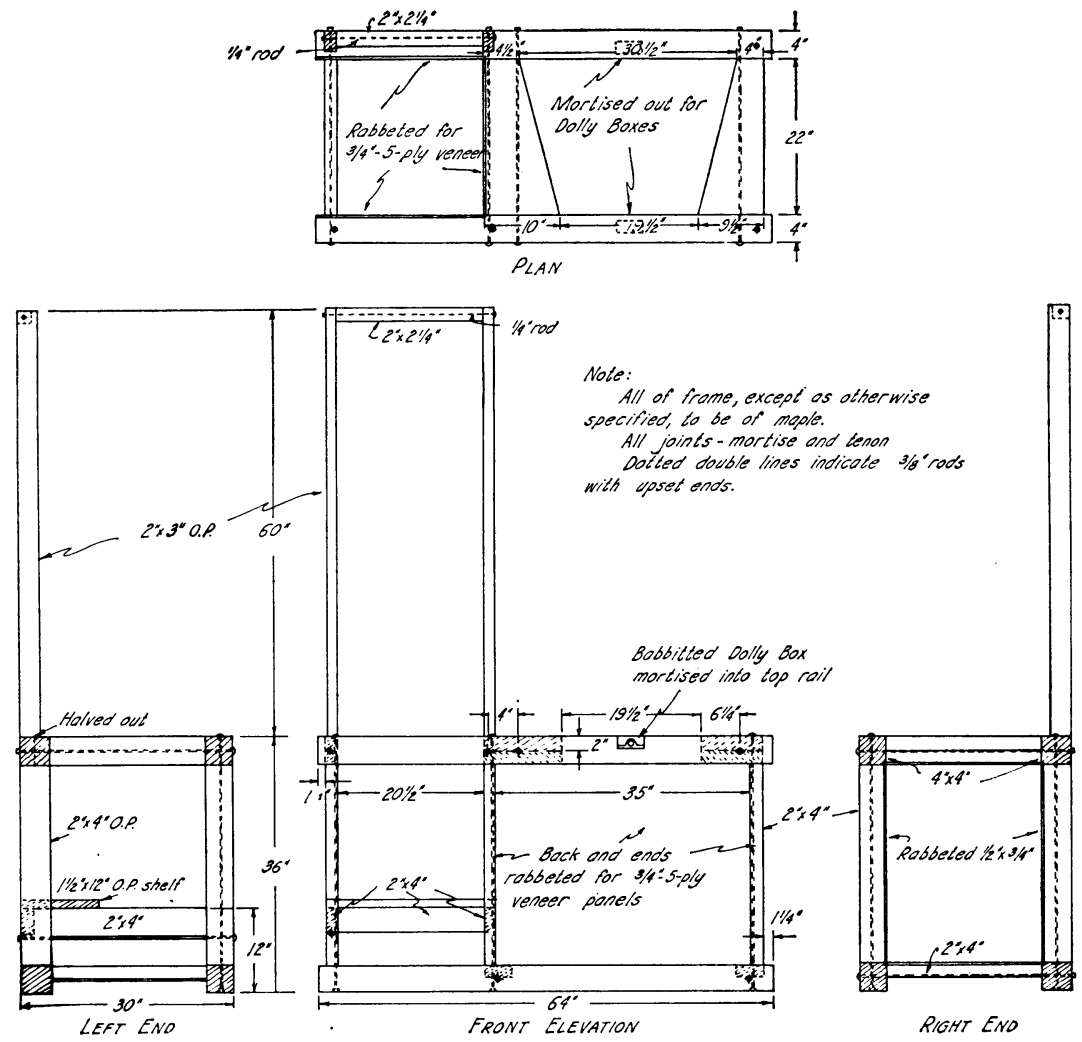

Fig. 1.-Framing plan and elevations of frame of fleece opener.

vibration or atmospheric changes can be compensated for by tightening the nuts.

Front and end elevations of the entire machine are shown in figure 2.

Hinges.-Loose-pin butts are used throughout with the exception of those on the three drop leaves. The pins are discarded, and in their place are inserted finishing nails of the same diameter as the original pins. These nails are bent at right angles to facilitate removal when the cages are to be collapsed or a part removed for cleaning.

Screens.-The ordinary galvanized fly screen used in the mixing and delivery cages is put on flush with the inside edges of the wooden screen frames to prevent lodging of small bits of wool on the frames. 


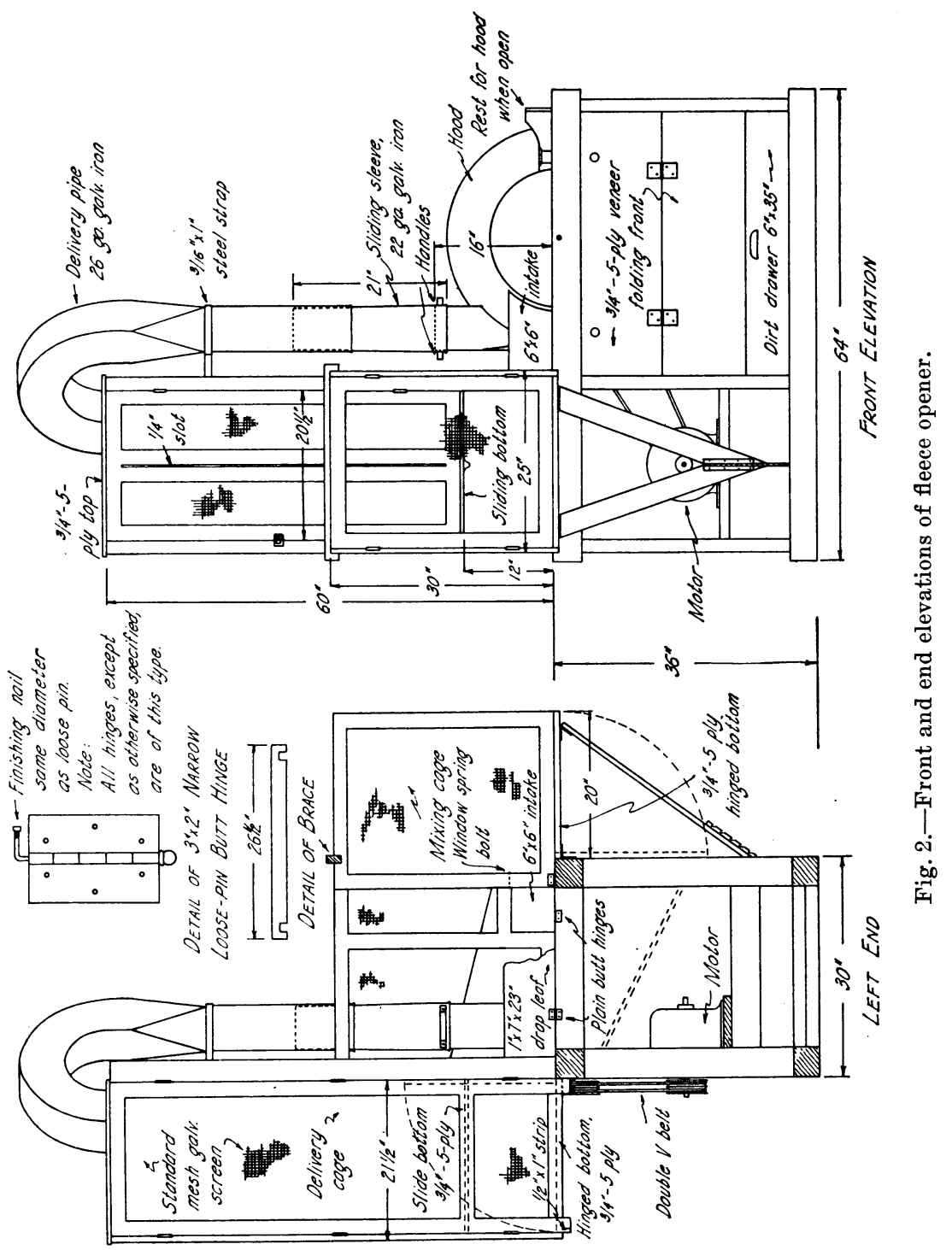



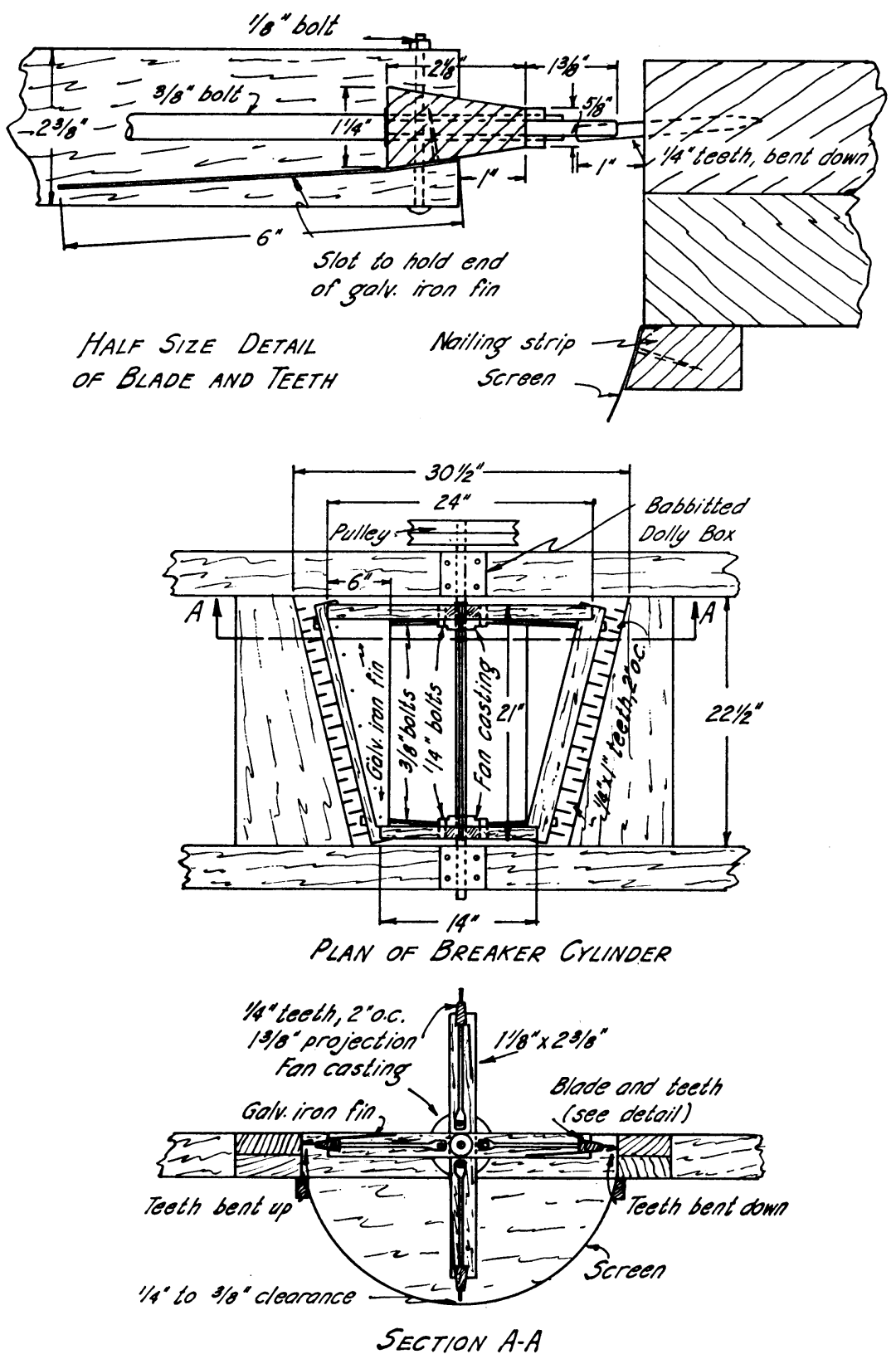

Fig. 3.-Construction and setting of cylinder. 

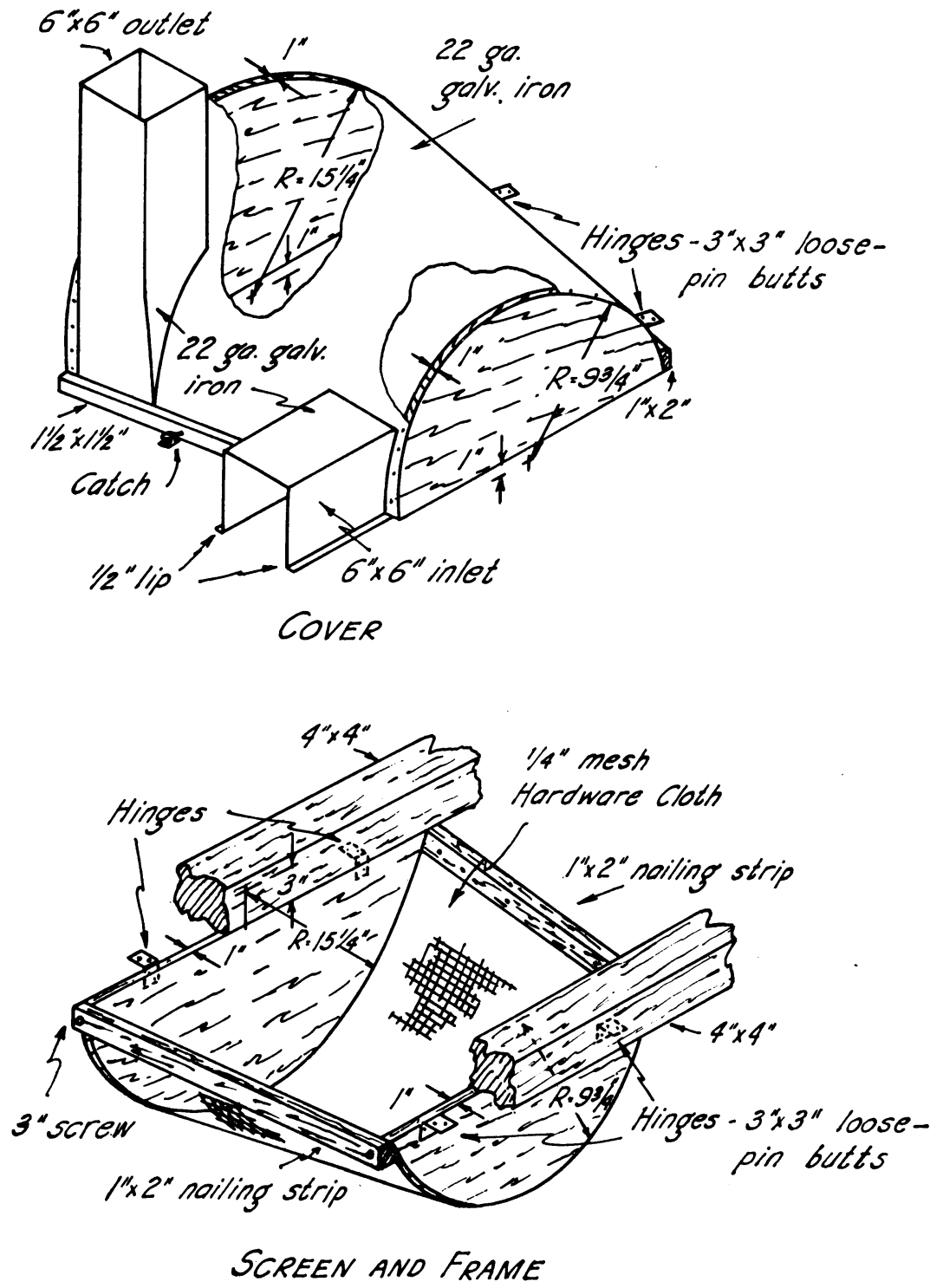

Fig. 4.-Detail of construction of cover and dirt screen.

Slot.-In the front elevation (fig. 2) there is shown a $1 / 4$-inch slot in the door of the delivery cage. Large samples of wool or single fleeces of the coarser grades may become so bulky from the action of the opener that the delivery cage will not hold the entire sample or fleece. The slot 
permits the insertion of a yardstick or piece of strap iron to compress such wools into a smaller bulk.

Figure 3 shows the construction and setting of the rotor or cylinder. Fan Castings.-The fan castings used for making the rotor are ob-

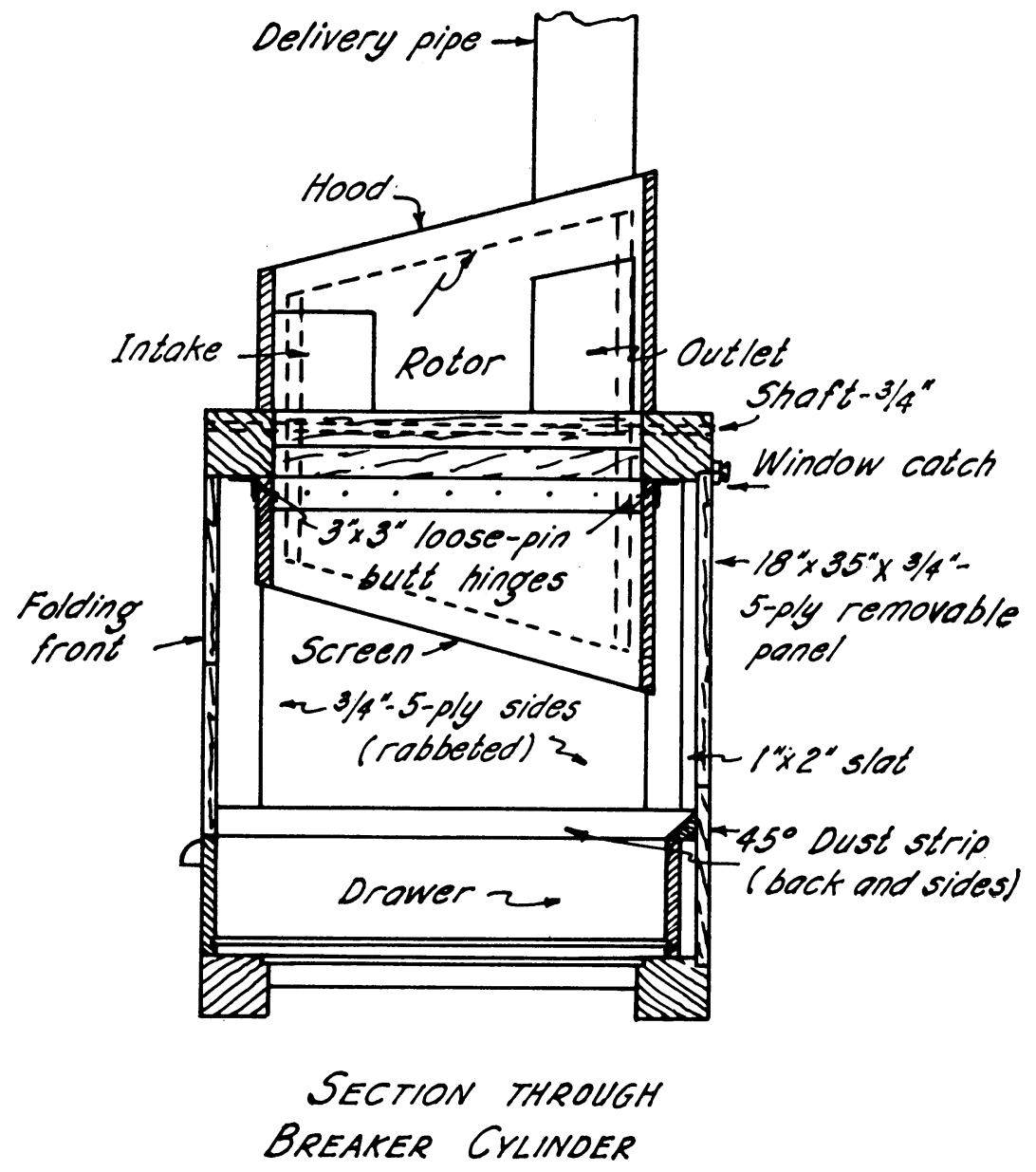

Fig. 5.-Relation among various parts of fleece opener, and construction of dust strips.

tainable from any manufacturer of threshing equipment, seed cleaners, and similar equipment.

Cylinder Teeth.-The teeth of the cylinder are 60-penny spikes cut off to proper length, with the ends made half spherical by filing. The pointed ends of these spikes, with the distal ends similarly rounded, are set in the frame. Holes drilled in the wood to receive the teeth are somewhat 
smaller than the teeth, and the teeth are coated with glue before being driven into place.

Fins.-Each of the four blades of the cylinder has on its face a fin of 22-gauge galvanized iron running the full length of the cylinder. These

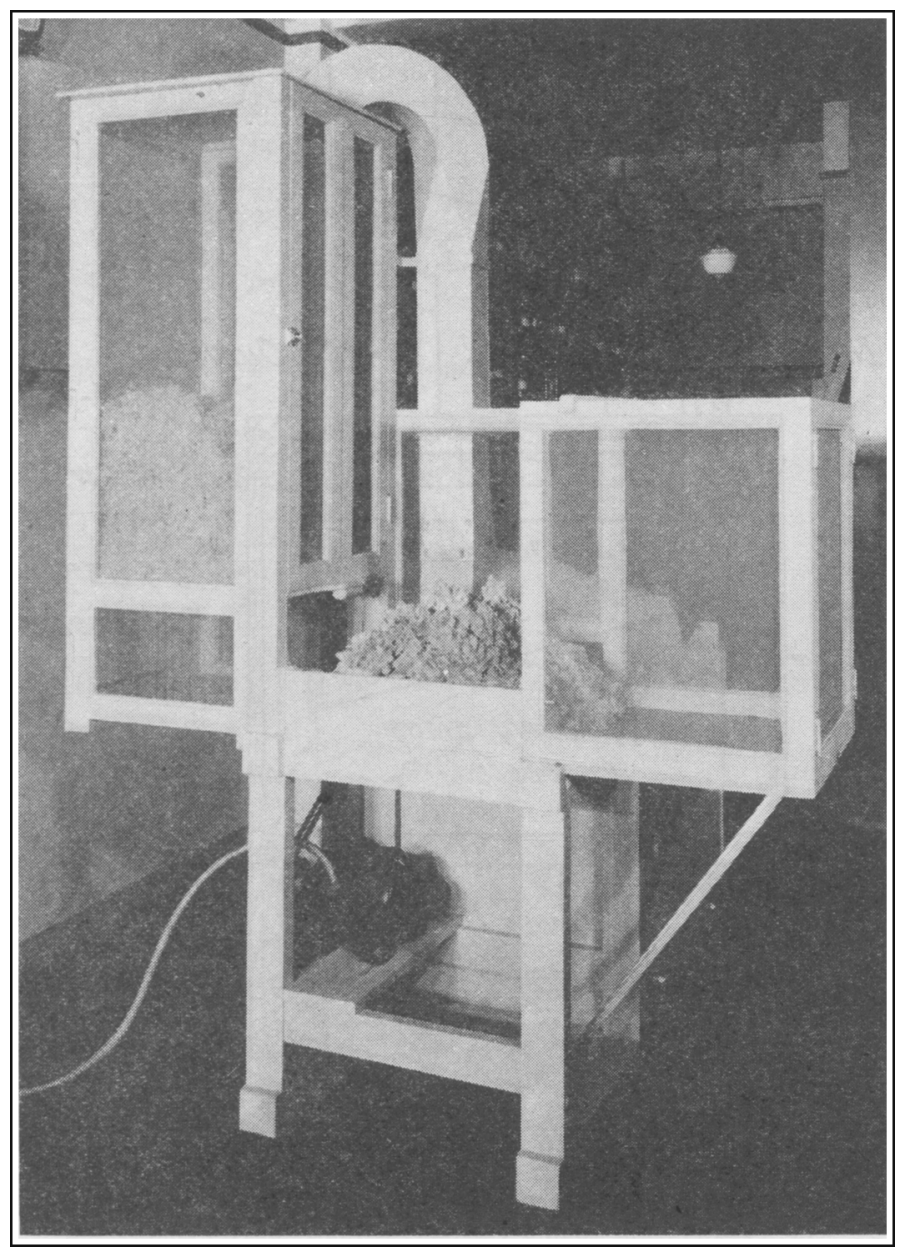

Fig. 6.-Front view of fleece opener.

fins greatly increase the air blast and help move the wool up the delivery pipe into the delivery cage.

At the top of figure 4 is shown the construction of the hood or cover. The point of juncture between the outlet pipe and the curved surface of the cover should be slightly rounding instead of acutely angular as 
shown in the figure. The wooden ends of the cover are of seasoned fir. They are not complete semicircles, the radii shown being those from the center of the shaft of the cylinder to the circumference of the wooden ends of the cover. The same statement applies to the radii of the ends of the dirt screen.

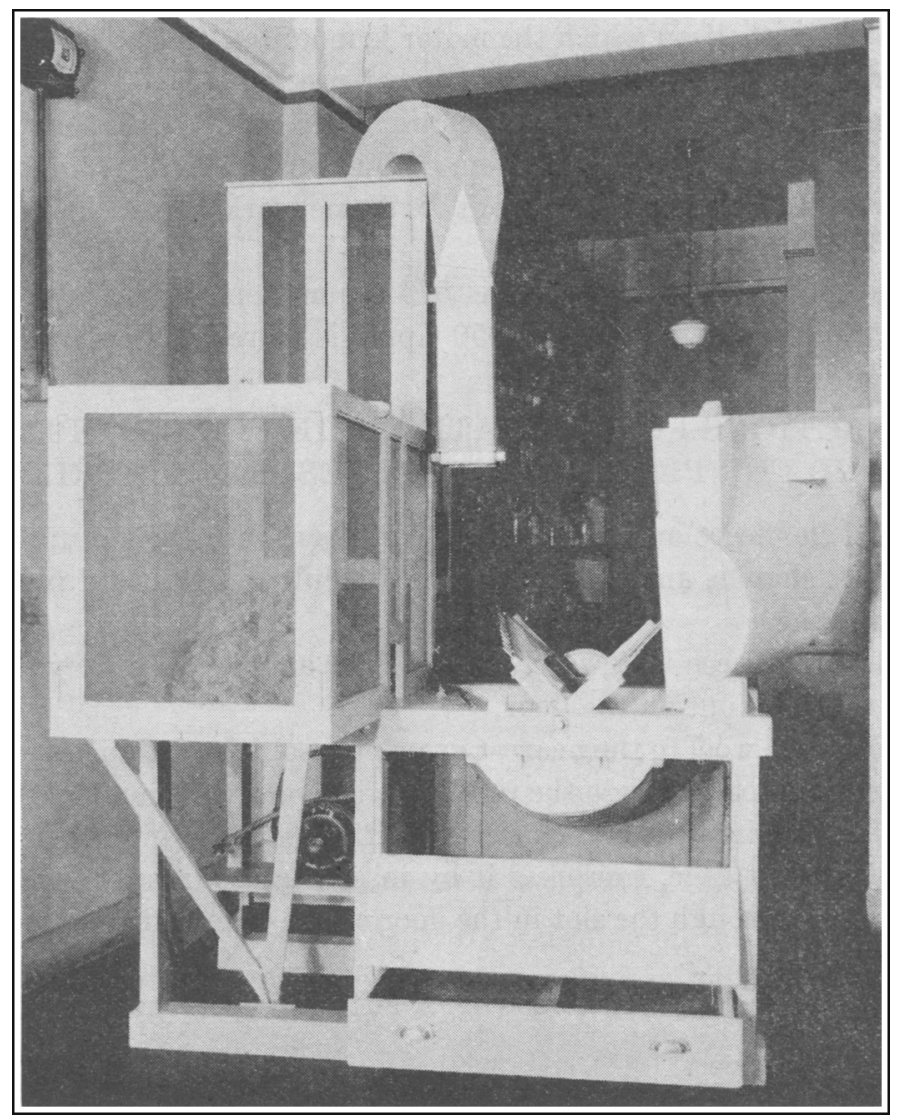

Fig. 7.-Side view of fleece opener, showing sleeve and cover raised, dirt drawer open, and folding front down. The removable panel (fig. 5) may be seen in the rear of the dust box.

The dirt screen (fig. 4, bottom) is made removable by the use of loosepin hinges. As wool grease collects, the screen must be removed occasionally and scrubbed with a hot sal soda solution. By opening the " 5 -ply veneer folding front" (fig. 2), taking out the "removable panel" (fig. 5), and slipping the belts off the pulleys, one can easily take the screen out.

Figure 5 shows a section through the machine and the relation among 
the various parts. The drawer holds the dirt knocked out of the wool by the action of the cylinder. Strips triangular in cross section are nailed around three sides of the lower eylinder housing and guide the dirt into the drawer.

Motor.-A 3/4-hp. repulsion-induction motor of 1150 r.p.m. is used. To permit change of motor position when necessary, slots instead of holes are cut in the shelf on which the motor is mounted (figs. 6 and 7).

Pulleys and Belts.-The pulleys are of pressed steel--two 5-inch and two 6-inch for the motor shaft; two 8-inch and two 10-inch for the cylinder shaft. They are obtainable from mail-order houses or from manufacturers of wood-working equipment for home workshops. The belts used are of the double $\mathrm{V}$ type.

Cylinder Speed.-The speed is 575 r.p.m. for most wools; but for coarse wools with long staple, 1050 r.p.m. is more satisfactory.

\section{DIRECTIONS FOR OPERATING THE FLEECE OPENER AND FOR PREPARING SAMPLES FOR SCOURING}

1. Spread the fleece or sample on a clean floor, with the tip up. Remove tags, fribs, shanks, and other portions difficult to scour and place them in a paper bag.

2. Place the fleece in a weighed container and add to it any dirt that may have fallen out on the floor.

3 . Weigh the wool to the nearest gram on a solution balance.

4. Feed the wool through the intake of the opener by handfuls until all has been blown into the delivery cage. If the fleece or sample is too bulky for the delivery cage, compress it by inserting a narrow stick or piece of strap iron through the slot in the door of the eage and pressing downward.

5. Pull out the "slide bottom" (fig. 2, left) and open the door of the delivery cage.

6. Mix the wool with the arms for about a minute, push the mass to the right side of the mixing cage, insert the "slide bottom," and close the door of the delivery cage.

7. Repeat directions 4,5 , and 6 at least twice.

8. Lower the "drop leaf" (fig. 2, left), and rake the wool out into the weighing basket (fig. 8).

9. Raise the "sliding sleeve" (fig. 2, right), raise the cover, and recover any locks of wool that may be left in the machine. If desired, one end of the dirt screen under the cylinder may be lowered by removing the improvised hinge pins. 
10. Weigh the wool and withdraw five or six samples of 200 grams each. The samples are made up of successive handfuls taken from various places in the weighing basket. Of these, three are used for the scouring test; the others are had for scouring only in the event that the first

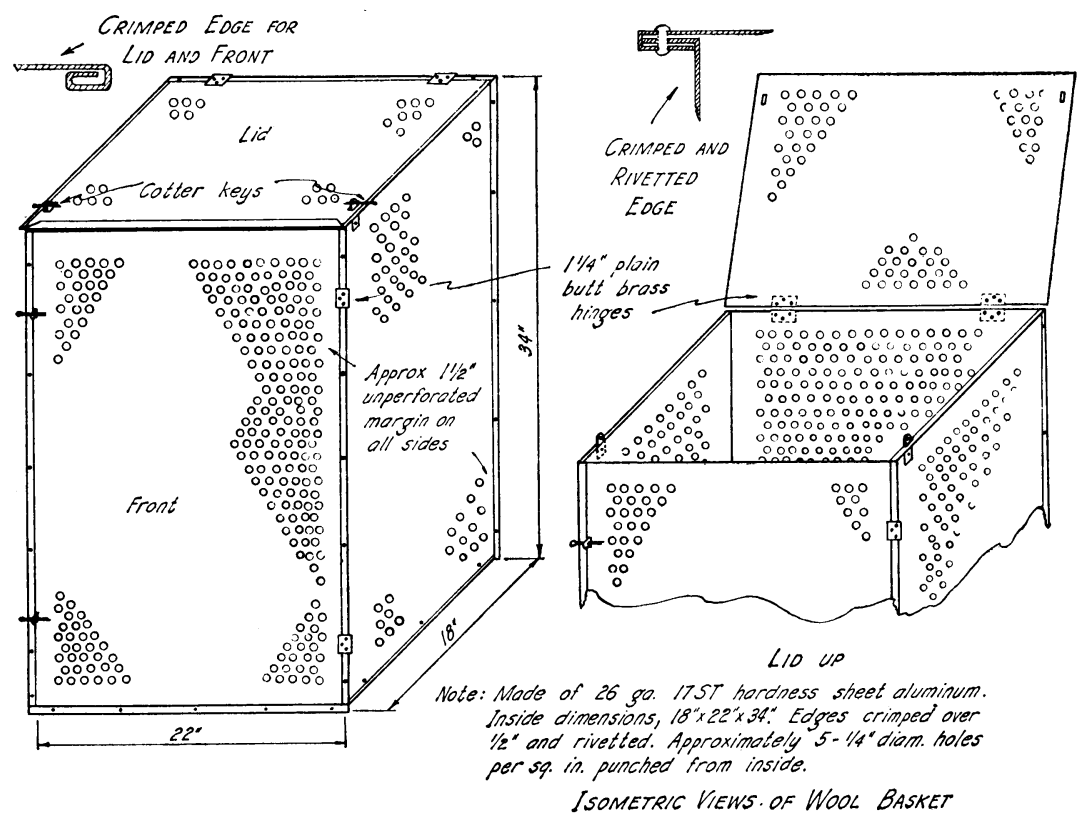

Fig. 8.-Weighing basket designed for use with the fleece opener. Both the lid and the front are hinged. When wool is removed from the fleece opener, the lid is opened; when samples for scouring are to be made up, the lid is closed, the basket is laid on its side, and the front (which then becomes the lid) is opened. Although the basket weighs only about $81 / 2$ pounds, it is roomy enough for the largest fleece.

three fail to agree within 1 per cent. By weighing out all the samples at once, one eliminates changes in weight due to fluctuations in atmospheric moisture.

11. Weigh the tags obtained in 1 above. Discard the string, straw, and other extraneous matter not removable by scouring; these are part of the shrinkage and must be weighed with the tags.

12. Run the tags through the opener one or more times to prepare them for scouring.

\section{SCOURING THE SAMPLES}

Alkali.-Crude sodium carbonate, or soda ash, sometimes called sal soda $\left(\mathrm{Na}_{2} \mathrm{CO}_{3}+\mathrm{Na}_{2} \mathrm{HCO}_{3}\right)$ is used largely as a water softener, and is available everywhere under various trade names. The amount to be used in each tub varies with the hardness of the water and with the greasiness 
of the wool. At Davis, California, the water is moderately hard; for scouring most fine wools soda ash (58 per cent) is added at the rate of about 10 grams to each gallon of water. Very greasy wools require about 12 grams to each gallon of water, coarse wools about 8 or 9 grams. Too much soda ash will overscour the wool and make it harsh $;{ }^{(3)}$ too little will cause the scoured wool to be greasy and not free of odor.

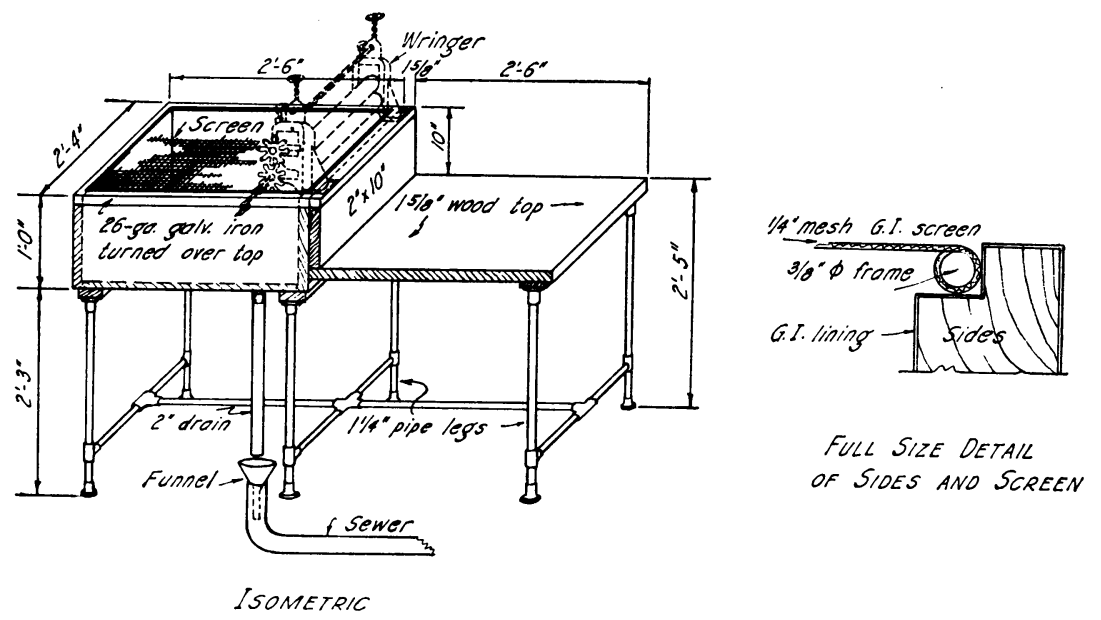

Fig. 9.-Wringer and stand. The stand consists of a 26 -gauge galvanized-iron tray, mounted within a wooden box. The wooden box has a cover of $1 / 8$-inch mesh galvanized screen (removable). Samples of wet wool are laid out on the sereen; the exeess water drains through the "gooseneck" into the sewer. The stand is movable and when in operation is placed with the "gooseneck" over a large funnel set in a sewer drain. The wooden apron on the right side of the stand is set at a lower level to accommodate the height of the screen-bottomed trays used in scouring.

The soda ash, if finely divided, may be added directly to the hot water provided it is stirred until all is dissolved. A safer plan, however, is to dissolve the soda ash first and add the solution.

Soap.-Olive-oil soap, made especially for wool scouring, should be used if possible. This is a potash soap that comes in a concentrated, gelatinous mass. It should be diluted with water in the proportion of 3 parts to 1 of soap and boiled until the solution is homogeneous, care being taken to replace water lost by vaporization. This soap stock may be kept in glass containers. It is sufficiently liquid to be readily soluble in warm water. If olive-oil wool-scouring soap is not available, neutral or nearly neutral soap flakes (97 per cent), such as Ivory or Lux, may be substituted, diluted as given above.

The amount of soap required depends on the kind of wool being scoured. The safest guide is the appearance of the soap bubbles on the 
wringer rolls when the wool is put through the wringer (fig. 9). When bubbles appear freely as the wringer is turned, but disappear in a few seconds when it is stopped, the amount of soap is correct. Too much will cause the wool to become matted and will make its thorough scouring almost impossible; too little will not emulsify the wool grease.

After samples for scouring have been weighed, a considerable quantity of the same lot of wool will usually remain. Handfuls of about 100 grams of this wool may be used for determining the correct amount of soap in each tub.

Under conditions prevailing at Davis, California, the required amount of the 3:1 soap mixture for each gallon of water is approximately as follows :

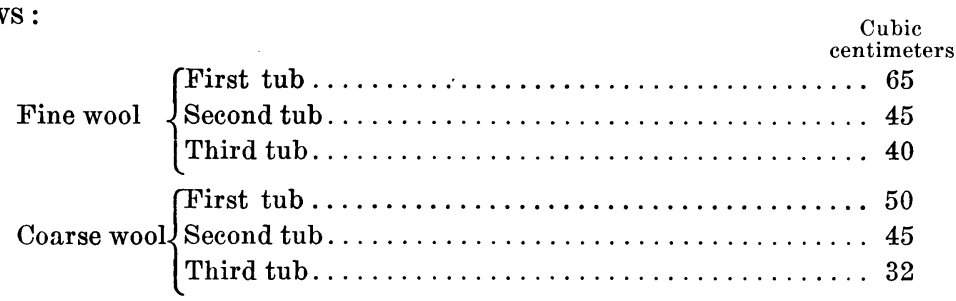

These figures, however, should serve only as a general guide. There is less danger of getting too much soap in the first tub than in the others, particularly in scouring fine wools.

Temperature of the Scouring Bath.-For experimental shrinkage tests, a temperature of $120^{\circ} \mathrm{F}$ is recommended for all three tubs used in actual scouring. The fourth tub, used for rinsing, may be somewhat cooler and not so well controlled. Scouring tags may take temperatures as high as $140^{\circ}$.

Manipulation of the Sample.-The sample is spread out in the screenbottomed scouring tray into a fairly uniform layer, and the trap is immersed in the first tub. The wool is agitated gently with a smooth wooden paddle for 3 minutes. It must not be stirred or agitated violently or moved about from one end of the tub to the other. The paddle is used merely to agitate the scouring bath, setting up currents of soapy water that emulsify the wool grease. At the end of 3 minutes the tray is lifted out and quickly turned upside down on the screened portion of the wringer stand. If skillfully manipulated, the mass of wool falls on the screen in an even, rectangular shape. The sides of the mass are then folded inward to make a roll of wool that can easily be fed through the wringer. The distal end of the roll, farthest removed from the wringer, is lifted up and fed through first. All this must be accomplished quickly because the effectiveness of the wringer, in both commercial and labora- 
tory scouring, depends on flushing out a large volume of scouring solution in a short time. If the stock is allowed to lie on the screen until it is well drained, obviously much of the possible flushing action of the wringer will be lost.

After passing through the wringer, the sample is caught in the tray and immersed in the second tub. This operation is repeated until the

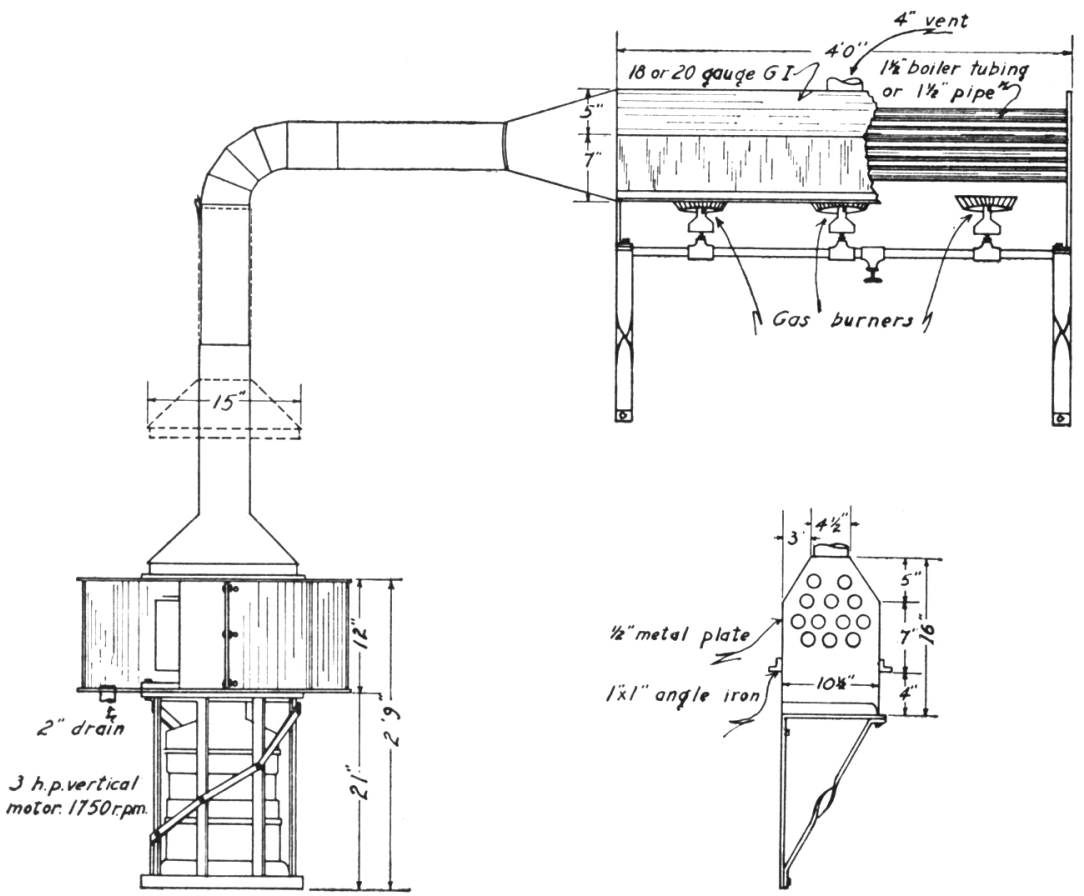

ELEVATION

Fig. 10.-Drier for samples of scoured wool. A 11/2-hp vertical repulsion-induction motor is directly connected with a Sturtevant multivane blower. A circular basket with sheet-metal bottom and copper fly-screen periphery fits inside the vanes of the blower. The wet wool is placed inside the basket. A funnel-shaped cap, directly above the air intake of blower, is lowered by means of a sliding sleeve and fits over the air intake. Air is pulled through a number of 2-inch pipes mounted in an open-bottomed sheet-metal box and heated by three large gas burners. Thus the air passing through the blower must pass through the wool; and since this air is preheated, drying is accomplished rapidly.

wool has passed through three tubs. It is then rinsed in warm water for about a minute and placed in the drier. The rinse water may be acidified with acetic acid when hard water is used.

All tags removed from the fleece are scoured until the locks and fribs are clean. It may be necessary to put them through the first tub and the 
wringer several times before using the second and third tubs. No attempt should be made to scour the tags as white as the main body of the fleece. In calculating shrinkages, the grease weight of the tags is added to the net grease weight of the fleece, and the scoured weight of the tags is added to the calculated scoured weight of the fleece.

As was shown in a previous publication, ${ }^{(3)}$ a large number of samples may be effectively scoured before the solutions need be changed, although, obviously, the baths should be changed oftener for some types of wools than for others; a convenient and practicable plan is to change the solutions each half day. Good results cannot be secured if the scouring bath is reheated after being used and is allowed to cool.

Drying.-The scoured sample may be put through the wringer a fourth time to remove the excess water from the rinse and then spread out to dry. Drying should be done in a dust-free room; otherwise the shrinkage will be lowered. Drying out of doors is dangerous because when the sample approaches dryness, it is so light that even a gentle breeze is apt to carry part of it away. Many types of commercial and laboratory driers are available on the market. The one found most satisfactory at the California Station is homemade and employs a combination of centrifugal force and hot air (fig. 10). After the pipes are well heated, air is delivered to the blower at about $160^{\circ} \mathrm{F}$, the proper temperature for drying wool. With this machine, wool completely saturated can be reduced to less than air dryness in about 7 minutes.

Conditioning the Scoured Samples.--The weight of the scoured sample should be placed on a standard moisture or standard regain basis. The most accurate and simple means of doing this is to dry the sample in a conditioning oven to constant weight at $220^{\circ} \mathrm{F}$. To the weight thus obtained is added 13.6 per cent, the standard regain for scoured wool adopted by the American Society of Testing Materials. ${ }^{(4)}$ Another method of accomplishing the same results is to allow the air-dry sample to remain for about 24 hours in a room controlled at $70^{\circ} \mathrm{F}$ and approximately 54 per cent relative humidity. According to Hartshorne, ${ }^{(5)}$ these atmospheric conditions should cause a regain in wool of about 13.6 per cent. 
Recording Data and Calculating Results.-The following record, taken from the files of this station, shows how data are recorded and results calculated :

Fleece No.......30

Grown by........ Crane Brothers

Address......... Santa Rosa, California
Breed..........Corriedale ewe

Date sheared...May, 1987

Days' growth... About 10 months

Gross grease weight....7907 grams

Weight of basket......4522 grams

(a) Net grease weight.. 3385 grams

Gross machine weight. ...7521 grams

Weight of basket.......4522 grams

(c) Loss in machine $(a-b) \ldots \ldots \ldots \ldots . \ldots 86$ grams

(d) Per cent loss in machine $\left(\frac{c}{a}\right) \ldots \ldots 11.40$

\section{SCOURING RECORD OF SAMPLES}

\begin{tabular}{|c|c|c|c|c|c|}
\hline No. & $\begin{array}{l}\text { (e) } \\
\text { Grease } \\
\text { weight }\end{array}$ & $\begin{array}{l}(f) \\
\text { Calculated original } \\
\text { grease weight } \\
\mathrm{e} \div\left(1-\frac{\mathrm{d}}{100}\right)\end{array}$ & $\begin{array}{l}\text { (g) } \\
\text { Scoured } \\
\text { weight } \\
\text { oven-dry }\end{array}$ & $\begin{array}{c}(\mathrm{h}) \\
\begin{array}{c}\text { Conditioned } \\
\text { weight } \\
(\mathrm{g} \times 1.136)\end{array}\end{array}$ & $\begin{array}{c}\text { (i) } \\
\text { Yield } \\
\left(\frac{\mathrm{h}}{\mathrm{f}} \times 100\right)\end{array}$ \\
\hline & grams & grams & grams & grams & per cent \\
\hline 1 & 200 & 225.7 & 124.5 & 141.43 & 62.66 \\
\hline 2 & 200 & 225.7 & 125.4 & 142.45 & 63.12 \\
\hline 3 & 200 & 225.7 & 125.0 & 142.00 & 62.91 \\
\hline
\end{tabular}

Total 188.69

(j) Average yield, per cent 62.9

(k) Calculated clean weight of fleece, less tags $\left(\frac{a \times j}{100}\right) \ldots 2129 \quad$ grams

(l) Clean weight of tags (oven-dry weight $\times 1.136$ ) ... 77.5 grams

(m) Calculated total clean weight of fleece $(\mathrm{k}+1) \ldots \ldots \ldots 2206.5$ grams

(n) Calculated total clean weight of fleece $(k+1) \ldots \ldots \ldots \quad 4.85$ pounds

(o) Grease weight of tags.................... 217 grams

(p) Total grease weight of fleece $(a+o) \ldots \ldots \ldots \ldots \ldots$ 3602 grams

(q) Shrinkage of entire fleece $\left(100-\left[\frac{\mathrm{m}}{\mathrm{p}} \times 100\right]\right) \ldots \ldots \ldots . \quad 38.76$ per cent

Work done by............... Clarke

Date finished. $6-6-1937$

Calculations checked by......J.F. Wilson

Testing the Results.-For scientific work the residues, especially that of free fat, should be determined. The American Society of Testing Materials $^{(4)}$ has adopted the following maximum residues for properly scoured wools :

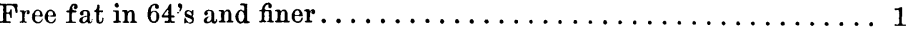

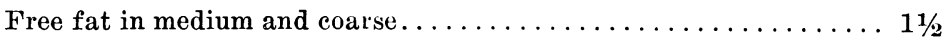

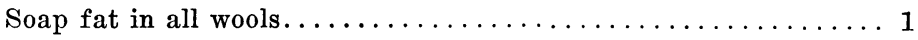

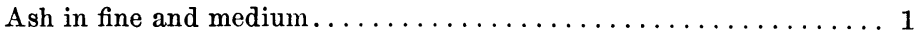

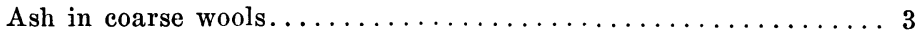


The Society also provides a standard procedure and standard methods of calculating the residues.

After the operator has developed the scouring technique, he should probably not need to determine the residues of soap fat and ash very often. If a large number of fleeces within the same grade and grown in the same locality are tested for shrinkage, duplicate composite subsam-

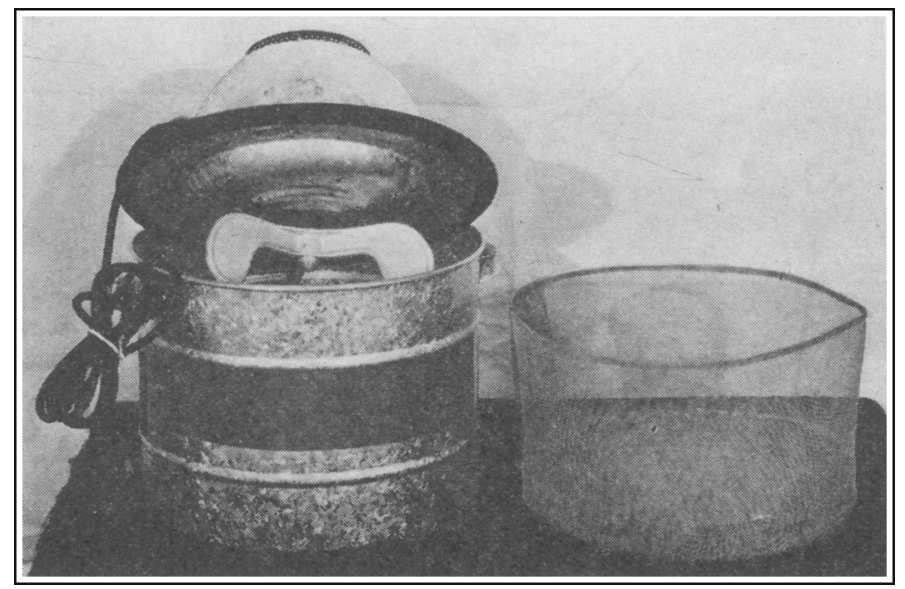

Fig. 11.-Electric washer used in wool-shrinkage tests. The screen basket was made to fit closely inside the tub and was held in place with small wire hooks on its rim. The bottom of the screen was 2 inches above the bottom of the tub, permitting dirt from the wool to fall through the screen.

ples of the scoured wool will show whether the work has been done properly. If the amounts of soap solution and soda ash required to produce a well-scoured wool of a certain description are recorded, the operator should be able to duplicate the results at any later time.

Tests of Various Laboratory Methods of Experimental Wool Scouring.-Scouring wool by hand with the equipment previously described is necessarily tedious if a large number of samples are scoured. Hardy ${ }^{(2)}$ found an electric washing machine designed for household use satisfactory. In a later publication ${ }^{(8)}$ he recommended sending wool samples to a commercial dry cleaner as a practical means of obtaining yields and stated that the results compared favorably with those obtained by other methods. Burns and Johnson ${ }^{(7)}$ have shown a close correlation between the yield of raw wool and its density under pressure, especially if the wool is dusted and mixed mechanically before being subjected to pressure.

Miller and Bryant ${ }^{(8)}$ evolved an apparatus for scouring small samples 
of wool. Their method, though applicable to certain fields of experimentation, is hardly suitable for yield and shrinkage determinations on large samples.

As a labor saver for the laboratory worker, either the electric washer or commercial dry cleaning has obvious advantages. It was decided,

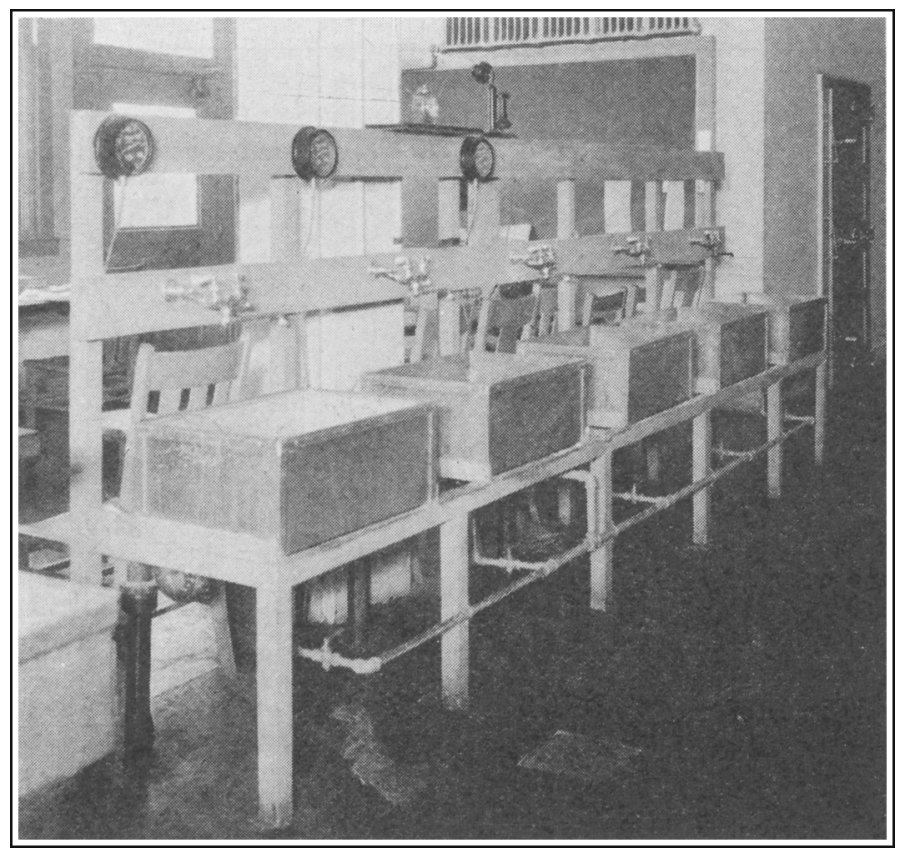

Fig. 12.-Equipment for sample-scouring at the University of California wool laboratory. The first three tubs are for the actual scouring; the fourth is for rinsing; the fifth, for making soap stock. Each of the tubs is fitted with a swinging-spout faucet, which, when pushed back, facilitates removal of the scouring trays. Note that the first three tubs are equipped with indicating-dial thermometers.

therefore, to compare each of these methods with the results obtained from hand scouring.

Most electric washers have the agitator on the bottom of the tub and do not readily lend themselves to the adaptation of a removable screen by which all the bits of scoured wool may be recovered. Recently, however, a washer of the type shown in figure 11, with the agitator mounted on the cover of the machine, has been placed on the market. Its small size made it seem ideally adapted to scouring samples of raw wool, and its structure permitted a removable screen container to be readily installed (fig. 11). 
Figures 12 and 13 show the construction and arrangement of samplescouring tubs and trays used at the University of California wool laboratory.

Because of the bulk of the samples, it seemed possible that the stock was too crowded in the washer. To ascertain whether or not there was actual crowding, samples 7 to 12 of each series tested with the electric washer were scoured in an ordinary galvanized iron washtub fitted with

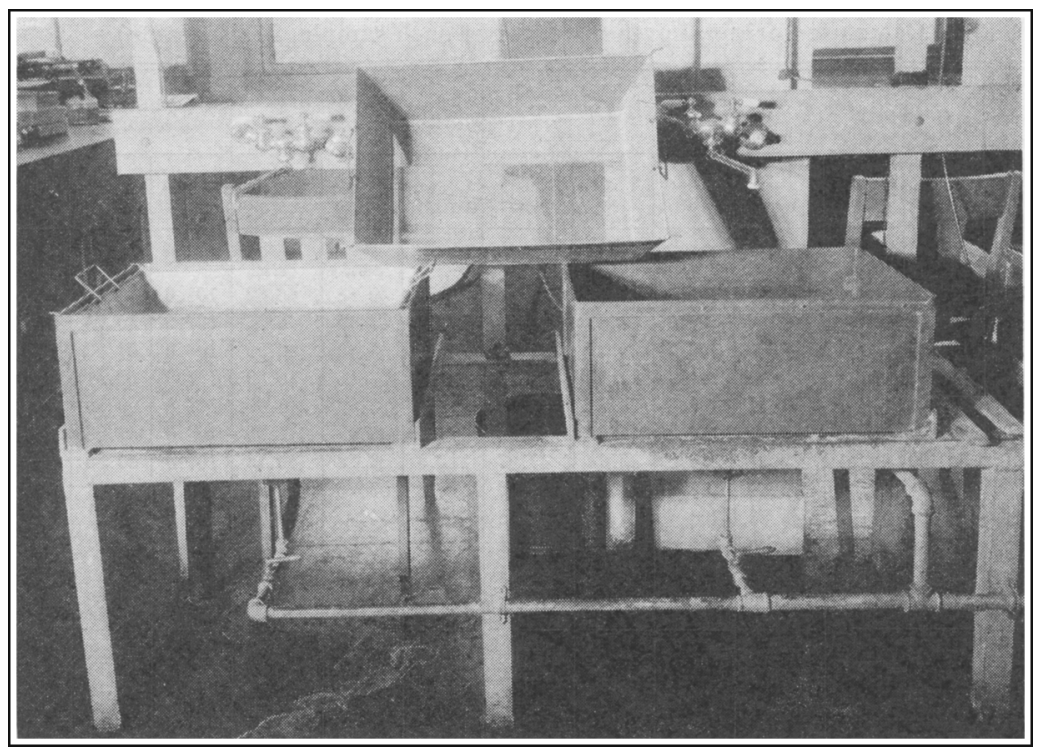

Fig. 13.-The scouring tubs are $16 \times 24 \times 10$ inches deep; the screen-bottomed trays are $151 / 2 \times 231 / 2 \times 8$ inches deep and are tapered toward the bottom. Small projecting hooks at the upper corners of the tray prevent it from resting on the floor of the tub.

a screen basket and with the agitator of the electric washer mounted on supports to do the work. Samples 1 to 6 of each series tested with the electric washer were scoured with the machine as shown in figure 11. The means of the results obtained with the first 6 samples of both the 64/70's French combing and the 46's combing compared with the remaining 6 samples of each series are contradictory. In the $64 / 70$ 's French combing the first 6 samples gave an average shrinkage of $48.24 \pm 0.18$ per cent; the last 6 averaged $48.60 \pm 0.15$ per cent. The first 6 samples of 46 's combing gave an average shrinkage $29.91 \pm 0.30$ per cent; the last 6 samples averaged $29.83 \pm 0.29$ per cent. Increasing the tub size thus gave a slightly higher shrinkage on the fine wool, while on the coarse the difference in shrinkage was not significant. 
Hundreds of small commercial dry-cleaning machines have been installed in recent years. Most of these employ carbon tetrachloride as the solvent and are so constructed that the material being cleaned can be extracted with any number of baths of clean solvent. The 200 -gram samples in this test were placed loosely in cheesecloth bags about $16 \times 24$ inches in size. The wool was spread out inside the bag in an even layer, and the

TABLE 1

Comparison of Scouring Methods Using 64/70's French Combing

(Calculated original grease weight of each sample, 211.4 grams)

\begin{tabular}{|c|c|c|c|c|c|c|c|c|c|c|c|c|}
\hline \multirow{2}{*}{$\begin{array}{l}\text { Sample } \\
\text { No. }\end{array}$} & \multicolumn{3}{|c|}{ Old method } & \multicolumn{3}{|c|}{ Electric washer } & \multicolumn{3}{|c|}{$\begin{array}{l}\text { Commercial dry } \\
\text { cleaning }\end{array}$} & \multicolumn{3}{|c|}{$\begin{array}{l}\text { Commercial dry } \\
\text { cleaning and rinse }\end{array}$} \\
\hline & $\begin{array}{c}\text { Clean } \\
\text { weight }\end{array}$ & Yield & $\begin{array}{l}\text { Shrink- } \\
\text { age }\end{array}$ & $\begin{array}{c}\text { Clean } \\
\text { weight }\end{array}$ & Yield & $\begin{array}{l}\text { Shrink- } \\
\text { age }\end{array}$ & $\begin{array}{c}\text { Clean } \\
\text { weight }\end{array}$ & Yield & $\begin{array}{l}\text { Shrink- } \\
\text { age }\end{array}$ & $\begin{array}{c}\text { Clean } \\
\text { weight }\end{array}$ & Yield & $\begin{array}{l}\text { Shrink- } \\
\text { age }\end{array}$ \\
\hline & grams & $\begin{array}{c}\text { per } \\
\text { cent }\end{array}$ & $\begin{array}{c}\text { per } \\
\text { cent }\end{array}$ & grams & $\begin{array}{c}\text { per } \\
\text { cent }\end{array}$ & $\begin{array}{c}\text { per } \\
\text { cent }\end{array}$ & grams & $\begin{array}{c}\text { per } \\
\text { cent }\end{array}$ & $\begin{array}{c}\text { per } \\
\text { cent }\end{array}$ & grams & $\begin{array}{c}\text { per } \\
\text { cent }\end{array}$ & $\begin{array}{c}\text { per } \\
\text { cent }\end{array}$ \\
\hline 1 & 106.0 & 50.14 & 49.86 & 109.0 & 51.56 & 48.44 & 113.5 & 53.68 & 46.32 & 108.0 & 51.08 & 48.92 \\
\hline 2 & 106.0 & 50.14 & 49.86 & 109.0 & 51.56 & 48.44 & 113.0 & 53,45 & 46.55 & 107.0 & 50.61 & 49.39 \\
\hline 3 & 106.0 & 50.14 & 49.86 & 108.5 & 51.32 & 48.68 & 113.0 & 53.45 & 46.55 & 108.0 & 51.08 & 48.92 \\
\hline 4 & 106.0 & 50.14 & 49.86 & 109.0 & 51.56 & 48.44 & 113.5 & 53.68 & 46.32 & 107.0 & 50.61 & 49.39 \\
\hline 5 & 108.0 & 51.09 & 48.91 & 110.0 & 52.03 & 47.97 & 114.0 & 53.92 & 46.08 & 107.5 & 50.85 & 49.15 \\
\hline 6 & 107.0 & 50.61 & 49.39 & 111.0 & 52.50 & 47.50 & 113.0 & 53.45 & 46.55 & 108.0 & 51.08 & 48.92 \\
\hline 7 & 106.0 & 50.14 & 49.86 & 110.0 & 52.03 & 47.97 & 112.5 & 53.22 & 46.78 & 107.5 & 50.85 & 49.15 \\
\hline 8 & 107.0 & 50.61 & 49.39 & 108.5 & 51.32 & 48.68 & 112.5 & 53.22 & 46.78 & 107.0 & 50.61 & 49.39 \\
\hline 9 & 106.0 & 50.14 & 49.86 & 108.5 & 51.32 & 48.68 & 112.5 & 53.22 & 46.78 & 107.0 & 50.61 & 49.39 \\
\hline 10 & 107.0 & 50.61 & 49.39 & 109.0 & 51.56 & 48.44 & 112.5 & 53.22 & 46.78 & 107.0 & 50.61 & 49.39 \\
\hline 11 & 106.0 & 50.14 & 49.86 & 108.0 & 51.09 & 48.91 & 114.5 & 54.16 & 45.84 & 107.5 & 50.85 & 49.15 \\
\hline 12 & 106.5 & 50.38 & 49.62 & 108.0 & 51.09 & 48.91 & 112.5 & 53.22 & 46.78 & 108.0 & 51.08 & 48.92 \\
\hline \multicolumn{3}{|l|}{ Totals.. } & 596.72 & & & 581.06 & & & 558.11 & & & 590.08 \\
\hline \multirow{2}{*}{\multicolumn{3}{|c|}{$\begin{array}{l}\text { Means. .................. } \\
\text { Standard errors. . . . }\end{array}$}} & 4964 & & & 48.42 & & & 46.51 & & $\ldots \ldots$ & 49.17 \\
\hline & & & \pm 0.07 & $\ldots \ldots$ & $\ldots$ & \pm 0.13 & & $\ldots \ldots$ & \pm 0.08 & $\ldots \ldots$ & $\ldots \ldots$ & \pm 0.06 \\
\hline
\end{tabular}

end of the bag sewed. The "pillow" thus made was tufted loosely in five places with needle and thread to prevent the contents from bunching at one end of the bags and to insure good penetration of the solvent.

If the solvent used in dry cleaning is truly "dry," a thorough cleaning should remove all the wool grease but not the suint. Suint, though only very slightly soluble in $\mathrm{C}_{6} \mathrm{H}_{6}$ or $\mathrm{CCl}_{4}$, is readily soluble in water. Accordingly, all the dry-cleaned samples were rinsed in clear warm water after being returned by the dry cleaner.

The wool involved in the test was a composite of several fleeces of each grade mixed by being put through the fleece opener five times before samples were drawn. All the samples were weighed before and after scouring, under the same atmospheric conditions. Table 1 gives the results of scouring, by each of three methods, 36 samples of $64 / 70$ 's French combing, grown in the northern coastal area of California.

Table 1 shows the results secured by each of three scouring methods. 
The old method of scouring by hand gave a slightly greater mean shrinkage than either the electric washer or the commercial dry cleaning followed by rinsing in warm water. Rinsing the dry-cleaned samples increased the average shrinkage of that group by 2.66 per cent, a fact which shows that the solvent used was reasonably free from water. That some of the suint was removed by the carbon tetrachloride is strongly

TABLE 2

Comparison of Scouring Methods Using 46's Combing (Calculated original grease weight of each sample, 230.4 grams)

\begin{tabular}{|c|c|c|c|c|c|c|c|c|c|c|c|c|}
\hline \multirow{2}{*}{$\begin{array}{l}\text { Sample } \\
\text { No. }\end{array}$} & \multicolumn{3}{|c|}{ Old method } & \multicolumn{3}{|c|}{ Electric washer } & \multicolumn{3}{|c|}{$\begin{array}{l}\text { Commercial dry } \\
\text { cleaning }\end{array}$} & \multicolumn{3}{|c|}{$\begin{array}{l}\text { Commercial dry } \\
\text { cleaning and rinse }\end{array}$} \\
\hline & $\begin{array}{c}\text { Clean } \\
\text { weight }\end{array}$ & Yield & $\begin{array}{c}\text { Shrink- } \\
\text { age }\end{array}$ & $\begin{array}{l}\text { Clean } \\
\text { weight }\end{array}$ & Yield & $\begin{array}{l}\text { Shrink- } \\
\text { age }\end{array}$ & $\begin{array}{c}\text { Clean } \\
\text { weight }\end{array}$ & Yield & $\begin{array}{l}\text { Shrink- } \\
\text { age }\end{array}$ & $\begin{array}{c}\text { Clean } \\
\text { weight }\end{array}$ & Yield & $\begin{array}{c}\text { Shrink- } \\
\text { age }\end{array}$ \\
\hline & grams & $\begin{array}{c}\text { per } \\
\text { cent }\end{array}$ & $\begin{array}{c}\text { per } \\
\text { cent }\end{array}$ & $g r$ & $\begin{array}{c}\text { per } \\
\text { cent }\end{array}$ & $\begin{array}{c}\text { per } \\
\text { cent }\end{array}$ & $g$ & $\begin{array}{c}\text { per } \\
\text { cent }\end{array}$ & $\begin{array}{c}\text { per } \\
\text { cent }\end{array}$ & 28 & $\begin{array}{c}\text { per } \\
\text { cent }\end{array}$ & $\begin{array}{c}\text { per } \\
\text { cent }\end{array}$ \\
\hline 1 & 160.0 & 69.44 & 30.56 & 162.0 & 70.31 & 29.69 & 163.0 & 70.75 & 29.25 & 157.0 & 68.13 & 31.87 \\
\hline 2 & 160.0 & 69.44 & 30.56 & 161.0 & 69.88 & 30.12 & 163.0 & 70.75 & 29.25 & 157.0 & 68.13 & 31.87 \\
\hline 3 & 159.5 & 69.22 & 30.78 & 162.0 & 70.31 & 29.69 & 163.0 & 70.75 & 29.25 & 156.0 & 67.71 & 32.29 \\
\hline 4 & 160.0 & 69.44 & 30.56 & 161.0 & 69.88 & 30.12 & 163.0 & 70.75 & 29.25 & 156.5 & 67.93 & 32.07 \\
\hline 5 & 159.5 & 69.22 & 30.78 & 162.0 & 70.31 & 29.69 & 162.0 & 70.31 & 29.69 & 156.5 & 67.93 & 32.07 \\
\hline 6 & 161.0 & 69.88 & 30.12 & 161.0 & 69.88 & 30.12 & 162.5 & 70.53 & 29.47 & 157.0 & 68.13 & 31.87 \\
\hline 7 & 161.0 & 69.88 & 30.12 & 162.0 & 70.31 & 29.69 & 163.0 & 70.75 & 29.25 & 156.0 & 67.71 & 32.29 \\
\hline 8 & 161.0 & 69.88 & 30.12 & 162.0 & 70.31 & 29.69 & 162.0 & 70.31 & 29.69 & 156.0 & 67.71 & 32.29 \\
\hline 9 & 159.0 & 69.01 & 30.99 & 162.0 & 70.31 & 29.69 & 162.0 & 70.31 & 29.69 & 156.0 & 67.71 & 32.29 \\
\hline 10 & 161.0 & 69.88 & 30.12 & 161.0 & 69.88 & 30.12 & 162.5 & 70.53 & 29.47 & 156.5 & 67.93 & 32.07 \\
\hline 11 & 160.0 & 69.44 & 30.56 & 161.0 & 69.88 & 30.12 & 162.0 & 70.31 & 29.69 & 157.0 & 68.13 & 31.87 \\
\hline 12 & 160.0 & 69.44 & 30.56 & 162.0 & 70.31 & 29.69 & 162.5 & 70.53 & 29.47 & 156.0 & 67.71 & 32.29 \\
\hline \multirow{3}{*}{\multicolumn{3}{|c|}{$\begin{array}{l}\text { Totals................ } \\
\text { Means............... } \\
\text { Standard errors...... }\end{array}$}} & 365.83 & & & 358.45 & & & 353.42 & & & 385.00 \\
\hline & & & 30.49 & $\ldots \ldots$ & $\ldots$ & 29.87 & $\cdots$ & $\ldots \ldots$ & 29.45 & & $\ldots \ldots$ & 32.08 \\
\hline & & & \pm 0.09 & $\ldots$ & $\ldots$ & \pm 0.07 & ..... & $\ldots \ldots$ & \pm 0.06 & ..... & $\ldots \ldots$ & \pm 0.06 \\
\hline
\end{tabular}

indicated, however, by analyses of similar raw wools which gave suint contents considerably above 2.66 per cent. ${ }^{5}$ Though the differences in shrinkage obtained by the three methods appear not to be large, an analysis of the differences by means of Student's " $t$ "(9) value shows them to be highly significant, since they exceed 2.8 , the " $t$ " value at the 1 per cent level. Where the subscript " 0 " relates to the mean shrinkage by the old method, "e" the mean shrinkage from the electric washer, and "c" that from commercial dry cleaning, the " $\mathrm{t}$ " values for the shrinkage of the $64 / 70$ 's French combing, for the three different methods of scouring are as follows : $\mathrm{t}_{\mathrm{o}, \mathrm{e}}=8.8 ; \mathrm{t}_{\mathrm{o}, \mathrm{c}}=5.2 ; \mathrm{t}_{\mathrm{e}, \mathrm{c}}=5.6$. Corresponding values for the 46 's combing are $: \mathrm{t}_{\mathrm{o}, \mathrm{e}}=5.7 ; \mathrm{t}_{\mathrm{o}, \mathrm{c}}=14.7 ; \mathrm{t}_{\mathrm{e}, \mathrm{c}}=25.1$.

The results obtained from scouring 36 samples of 46 's combing are presented in table 2.

\footnotetext{
¿Unpublished data.
} 
As table 2 shows, the soap-and-soda method of scouring gave a significantly higher shrinkage than that obtained from the electric washer, while the samples dry-cleaned gave a higher mean shrinkage than either of the other two methods.

In both the $64 / 70$ 's French combing and the 46's combing, the electric washer agitated the stock so violently that the scoured wool was inclined to be ropy and somewhat felted. This was especially true of the fine wool. Conceivably, the felting caused by too much agitation prevented some of the dirt from precipitating and thus affected the results adversely.

TABLE 3

Per Cent of Free fat Extracted from Duplicate Composite SAMPLES OF SCOURED WOOLS

\begin{tabular}{|c|c|c|c|c|}
\hline Description & Sample No. & Old method & $\begin{array}{l}\text { Electric } \\
\text { washer }\end{array}$ & $\begin{array}{l}\text { Dry-cleaned } \\
\text { and rinsed }\end{array}$ \\
\hline $64 / 70$ 's French combing. . & $\left\{\begin{array}{l}1 \\
2\end{array}\right.$ & $\begin{array}{c}\text { per cent } \\
1.09 \\
1.04\end{array}$ & $\begin{array}{c}\text { per cent } \\
2.13 \\
2.19\end{array}$ & $\begin{array}{c}\text { per cent } \\
0.20 \\
0.20\end{array}$ \\
\hline 46's combing. & $\left\{\begin{array}{l}1 \\
2\end{array}\right.$ & $\begin{array}{l}1.27 \\
0.96\end{array}$ & $\begin{array}{l}1.35 \\
1.50\end{array}$ & $\begin{array}{l}0.08 \\
0.10\end{array}$ \\
\hline
\end{tabular}

Using a large tub with the washer appeared to be slightly beneficial for the fine wool but not for the coarse.

In the entire series of experiments the shrinkages obtained for any one set of samples appear surprisingly uniform. One must remember that the samples were weighed on a solution balance only to the nearest interpolated half gram, a procedure that partially accounts for the uniformity. Both lots of wool, furthermore, were mixed in the fleece opener with meticulous care for the purpose of comparing scouring methods. Ordinarily, in testing the shrinkage of fleeces by scouring 3 samples, one does not expect such striking uniformity of results.

The percentage of free fat left in the samples of scoured wool is indicated in table 3 .

As table 3 shows, the wools scoured by the soap-and-soda method were barely above the American Society of Testing Materials standard for free fat for a well-scoured fine wool; the coarse wool was within the limit of tolerance. The per cent of free fat in the wools scoured by the electric washer was significantly higher than in those scoured by the old method, even though the scouring solution, temperature, and time factors were identical. The per cent of free fat in the dry-cleaned samples was extremely low. These differences partly account for the differences in mean shrinkages. 
Laboratory Scouring Compared with Commercial Scouring.-In laboratory shrinkage tests the scoured stock need not be strictly comparable in physical characteristics to that obtained from commercial scouring; nevertheless, the shrinkage data obtained should be nearly identical. In all probability orthodox commercial scouring never results in a scoured product with a percentage of free fat as low as that obtained in these trials by dry cleaning. Possibly, too, if a scoured wool so defatted were dry-combed, the top would give trouble in drawing and spinning. In these tests, the old method of scouring produced a scoured product comparable in every way with that which might be expected from first-class commercial plants. The same cannot be said of the other two methods, one of which failed to remove enough of the wool grease, the other possibly too much.

Some agricultural experiment stations have sent fleeces grown experimentally to commercial mills for scouring, applying the shrinkage figure obtained to each of the fleeces in the shipment. Tests at the California Station ${ }^{(10)}$ have shown a variation of more than 24 per cent in the yield of individual fleeces shorn from ewes of similar breeding kept together during the entire growth period of the fleece. Similar data published by Bosman ${ }^{(1)}$ show that the yield of five plain-bodied South African Merino stud rams ranged from 32.7 to 57 per cent. Mill equipment is not adapted to scouring individual fleeces, and most mill shrinkage tests take entire bags of 200 pounds or more. It is obviously fallacious to apply, to each fleece in a lot, the shrinkage obtained on the entire quantity considered as a unit and then to use such data for biological studies. In the interest of accuracy, all biological studies demand that shrinkage be determined for each fleece individually.

The soap-and-soda method of scouring by hand yields excellent results, and its use is indicated where the highest degree of accuracy is desired. For certain types of experiments, either the electric washer or dry cleaning may be used. Both methods are easier and no more expensive than hand-scouring. Their great convenience as compared with hand-scouring and the fact that the shrinkage figures obtained by their use are not wholly out of line with hand-scouring suggest that either of them may be used under certain circumstances. 
${ }^{1}$ WILSON, J. F.

\section{LI'TERATURE CITED}

1937. Wool production and improvement of the elip in California. California Agr. Ext. Cir. 106:1-61.

2 Hardy, J. I.

1927. Methods of wool scouring suggested for sheep husbandry investigators. U. S. Dept. Agr. Bur. Anim. Indus. Booklet. 13 p.

${ }^{3}$ WILSON, J. F.

1928. A method of determining the clean weights of individual fleeces of wool. California Agr. Exp. Sta. Bul. 447:1-21. (Out of print.)

4 American Society of Testing Materials. Standards.

1936. Part II. Standard method of estimating hard scoured wool in wool in the grease. p. 232-36.

${ }^{5}$ Hartshorne, Wm. D.

1915. Unit system charts showing the relations between humidity and regains on wool and cotton. Natl. Assn. Wool Mfgrs. Bul. (Reprint). 20 p.

${ }^{8}$ HARDX, J. I.

1934. Wool yield and fleece density can be measured by a simplified method. U. S. Dept. Agr. Yearbook 1934:1-783.

${ }^{7}$ Burns, Robert H., and Alexander Johnson.

1936. Predicting the yield of raw wool from its density under pressure. Amer. Soc. Anim. Prod. Proc. 1936:1-341.

${ }^{8}$ Miller, W. C., and D. M. Bryant.

1932. An apparatus for scouring small samples of wool and a modified apparatus for determining dry weights. Jour. Textile Inst. 23(11):T267-T273.

${ }^{9}$ Fisher, R. A.

1928. Statistical methods for research workers. 2nd ed. Oliver and Boyd. London. $269 \mathrm{p}$.

${ }^{10}$ WILson, J. F.

1934. Combing tests with individual wool fleeces. Textile Research 4(1.2) : 570582.

${ }^{11}$ Bosman, Victor.

1937. Biological studies on South African Merino wool production. IV. Jour. Textile Inst. 28(9): 321-353. 